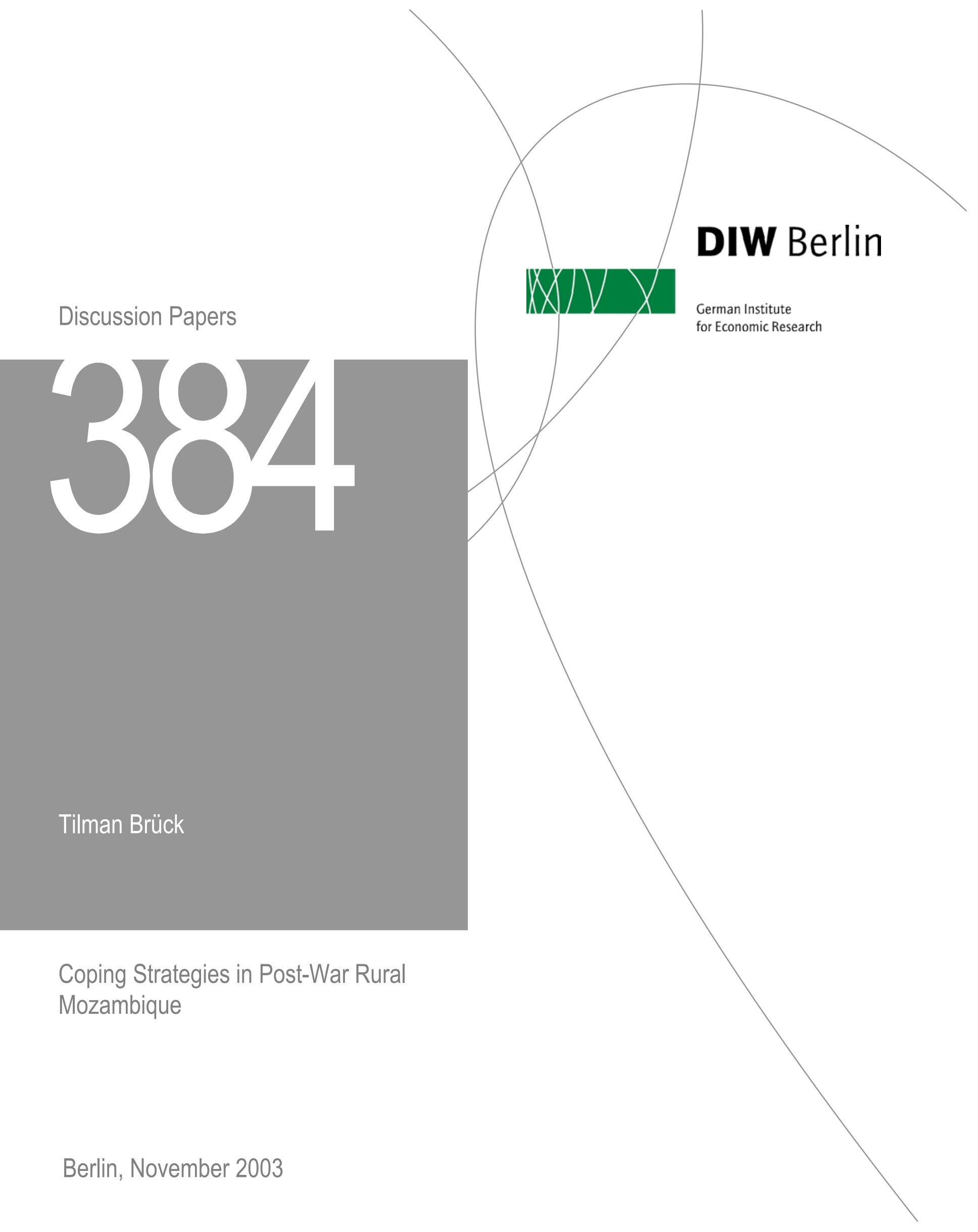


Opinions expressed in this paper are those of the author and do not necessarily reflect views of the Institute.

\section{DIW Berlin}

\section{German Institute}

for Economic Research

Königin-Luise-Str. 5

14195 Berlin,

Germany

Phone $+49-30-89789-0$

Fax +49-30-897 89-200

www.diw.de

ISSN 1619-4535 


\title{
Coping Strategies in Post-War Rural Mozambique
}

\author{
Tilman Brück
}

German Institute for Economic Research (DIW Berlin)

Königin-Luise-Str. 5, 14195 Berlin, Germany

Tel: +49-30-89789-591, Fax: +49-30-89789-108

Email: tbrueck@diw.de, Internet: http://www.tilmanbrueck.de

\section{November 2003}

JEL codes: J22, O12, O13, Q12

Keywords: coping strategies, activity choices, labour allocation, portfolio model, war, conflict, reconstruction, policy, Mozambique, Africa

\begin{abstract}
This paper analyses post-war coping strategies by farm households in developing countries. The analysis is based on a portfolio model of activity choices in war-affected rural SubSaharan Africa. A case study using farm household survey data estimates the determinants of agricultural coping strategies in post-war Mozambique. Post-war coping strategies differ from pre- and mid-crisis coping strategies. War-affected households are forced to adopt very risky coping strategies that re-enforce their vulnerability. Households choose between market and non-market forms of exchange and even consider exiting markets entirely. Post-war reconstruction policy should focus on re-capitalizing households, providing public goods and establishing markets.
\end{abstract}

\section{Acknowledgements}

I am very grateful for helpful comments from Tony Addison, Valpy FitzGerald, Pramila Krishnan, Marta Rosário, Caterina Ruggeri Laderchi, Frances Stewart, an anonymous referee and from seminar participants at QEH and the CSAE in Oxford. The data was generously made available by the Food Security Project of the Mozambican Ministry of Agriculture and Michigan State University. I benefited from a WIDER sabbatical fellowship while writing this article. The findings and views presented in this paper are those of the author and do not necessarily reflect the position of the above-mentioned individuals or institutions. 


\section{Introduction}

The traditional coping strategy literature has focused on household activity choices leading up to, and during, natural disasters and famine. In contrast, this paper analyses post-war coping strategies by farm households in developing countries. The analysis is based on a model of farm household behaviour which is derived from portfolio theory (Bodie and Merton 1998, Dixit 1990). The model considers the special circumstances of conflict in rural Sub-Saharan Africa, which are akin to a land abundant tropical economy (Binswanger and McIntire 1987, Chayanov 1925).

Initial contributions to the literature on coping strategies analysed responses to drought and famine (Corbett 1988, Reardon et al 1988). A related literature studied activity choices and income diversification (Ellis 2000, Reardon et al 1992). These choices are affected by household size and endowments (Abdulai and Delgado 1999, Bardhan and Udry 1999: p. 108, Taylor and Yunez-Naude 2000, von Braun and Pandya-Lorch 1991), by social institutions and property rights (Berry 1993, Brück 2003, Carter and Olinto 2003, Fafchamps and Lund 2003, Platteau 1999), by formal and informal markets or by their absence (de Janvry et al 1991, Key et al 2000, Leonard 2000, Liedholm et al 1994) and by location and geography (Dercon and Krishnan 1996, Goetz 1992). Coping strategies include the decision of whether to engage in markets at all (Binswanger and McIntire 1987), the choice of crop or production technique (Sperling and Longley 2002, von Braun and Kennedy 1994) and non-market forms of risk diversification (Blarel et al 1992, Dercon and Krishnan 2000). Policy makers are concerned about activity choices and their impact on rural poverty (Adams 2002, Dercon 2002), export earnings from cash crops (Townsend 1999) or as a means of mitigating the negative effects of disasters (Sperling and Longley 2002, Webb and von Braun 1994). The traditional literature has not, however, considered coping strategies and activity diversification in situations of war. 
In fact, there is very little analysis to date of the micro-economic behaviour of farm households in times of conflict. Hence the analysis of coping strategies after war is the unique contribution of this paper.

A case study using farm household survey data estimates the determinants of agricultural coping strategies in post-war Mozambique. There is a lively debate on income diversification and cash crop adoption in Mozambique (Cramer and Pontara 1998, Heltberg and Tarp 2002, Pitcher 1998, Tschirley and Benfica 2001, Tschirley and Weber 1994). Another literature records the economic effect of the devastating civil war in Mozambique (Addison and de Sousa 1999, de Sousa 2003, Wuyts 2003). This article differs from that literature by focusing on the long-term effects of war on farm household production choices.

The analysis demonstrates that post-war coping strategies differ from pre- and mid-crisis coping strategies. War-affected households have a higher demand for risk diversification yet they may be severely constrained in their activity choices. Such households are forced to adopt very risky coping strategies that re-enforce their vulnerability. Households choose between market and non-market forms of exchange and even consider exiting markets entirely, an option not often considered by basic models of farm household behaviour. Even after the end of the war, the household labour allocation will only slowly revert back to the peace-time optimal value. These findings have strong implications for post-war reconstruction policies.

The paper is structured as follows. The next sections develop a formal model of household coping strategies with two risky income activities and discuss the effects of war in the model. The subsequent section introduces the case study, reviews methodological and data issues and derives the econometric specification of the model. This is followed by a discussion of some 
summary statistics, the econometric results and policy implications. The last section concludes.

\section{A Model of the Determinants of Coping Strategy}

This section develops a simple model of the choice between two coping strategies. Activity or coping strategies refer to the household labour allocation between different income generating tasks. The main activity distinctions are between on- and off-farm (or agricultural and nonagricultural) activities and between subsistence and market activities.

Consider a farm household with two production activities $i=1$ or 2 . (The model can be generalized to more than two activities.) Assume that land is abundant and that there are no credit or labour markets: the total labour supply equals household labour supply L. Asset endowments of households are given in each period and are normalized at 1 . The main risk in household production derives from $\mathrm{V}$, the variance of portfolio revenue net of costs:

$$
\mathrm{V} \quad=\mathrm{s}_{1}{ }^{2}-2 \mathrm{q}\left(\mathrm{s}_{1}^{2}+\mathrm{s}_{12}\right)+\mathrm{q}^{2}\left(\mathrm{~s}_{1}^{2}+\mathrm{s}_{2}^{2}-2 \mathrm{~s}_{12}\right)
$$

such that:

$$
\mathrm{S}_{12} \quad=\rho_{12} \mathrm{~S}_{1} \mathrm{~S}_{2}
$$

where $\mathrm{q}_{\mathrm{i}}$ is the share of labour dedicated to activity $\mathrm{i}, \mathrm{s}_{\mathrm{i}}$ is the standard deviation of the return of the $i^{\text {th }}$ activity, $s_{12}$ is the covariance of returns between the two activities, and $\rho_{12}$ is the correlation coefficient of the returns from both activities. This yields:

$$
\begin{array}{ll}
\partial \mathrm{V} / \partial \mathrm{q}=-2 \mathrm{~s}_{1}{ }^{2}+2 \mathrm{qs}_{1}{ }^{2}+2 \mathrm{qs}_{2}{ }^{2}+2 \mathrm{~s}_{12}-4 \mathrm{qs}_{12} & \\
\partial \mathrm{V} / \partial \mathrm{q}=-2 \mathrm{~s}_{1}{ }^{2}<0 & (\text { for } \rho=0 \text { and } \mathrm{q}=0) \\
\partial \mathrm{V} / \partial \mathrm{q}=2 \mathrm{~s}_{2}{ }^{2}>0 & (\text { for } \rho=0 \text { and } \mathrm{q}=1) \\
\partial^{2} \mathrm{~V} / \partial \mathrm{q}^{2}=2 \mathrm{~s}_{1}{ }^{2}+2 \mathrm{~s}_{2}{ }^{2}-4 \mathrm{~s}_{12} &
\end{array}
$$




$$
\begin{array}{lrl}
\partial^{2} \mathrm{~V} / \partial \mathrm{q}^{2} & >0 & (\text { for } \rho=0) \\
\mathrm{q}_{\mathrm{Vmin}}=\mathrm{s}_{1}{ }^{2} /\left(\mathrm{s}_{1}{ }^{2}+\mathrm{s}_{2}{ }^{2}\right) & (\text { for } \rho=0)
\end{array}
$$

where $\mathrm{q}_{\mathrm{Vmin}}$ denotes the share of labour allocated to the second activity such that total portfolio risk is minimized. Total farm production $\mathrm{X}$ is defined as:

$$
\begin{aligned}
\mathrm{X} & =\mathrm{X}_{1}\left(\mathrm{~L}_{1}\right)+\mathrm{X}_{2}\left(\mathrm{~L}_{2}\right) \\
& =\mathrm{a}_{1} \mathrm{q}_{1}+\mathrm{a}_{2} \mathrm{q}_{2}
\end{aligned}
$$

where:

$$
\mathrm{L} \quad \mathrm{L}_{1}+\mathrm{L}_{2}
$$

and where $a_{i}$ is the activity-specific constant returns to scale (CRS) production technology. Total farm revenue net of variable, non-labour inputs $\mathrm{R}$ is given by:

$$
\begin{aligned}
\mathrm{R} & =\mathrm{R}_{1}+\mathrm{R}_{2} \\
& =\mathrm{p}_{1} \mathrm{X}_{1}+\mathrm{p}_{2} \mathrm{X}_{2}
\end{aligned}
$$

where $p_{i}$ are farm-gate output prices. Farm-gate prices are net of transaction costs $t_{i}$ so that:

$$
\mathrm{p}_{\mathrm{i}} \quad=\mathrm{p}_{\mathrm{i}}^{*}-\mathrm{t}_{\mathrm{i}}
$$

where $\mathrm{p}_{\mathrm{i}}{ }^{*}$ are given wholesale market prices. Transaction costs for each commodity are determined by given household characteristics and market imperfections. This implies that commodity prices and commodity market failure are household-specific.

At the beginning of the agricultural year, a household allocates its labour supply L between activities for a given set of expected revenues, preferences, endowments and local climatic conditions:

$$
\begin{aligned}
\mathrm{E}(\mathrm{R}) & =\mathrm{E}\left(\mathrm{p}_{1}\right) \mathrm{E}\left(\mathrm{X}_{1}\right)+\mathrm{E}\left(\mathrm{p}_{2}\right) \mathrm{E}\left(\mathrm{X}_{2}\right) \\
& =\mathrm{E}\left(\mathrm{p}_{1}\right) \mathrm{a}_{1}(1-\mathrm{q})+\mathrm{E}\left(\mathrm{p}_{2}\right) \mathrm{a}_{2} \mathrm{q}
\end{aligned}
$$


where:

$$
\begin{aligned}
\mathrm{q} & =\mathrm{q}_{2} \\
& =\mathrm{L}_{2} / \mathrm{L}
\end{aligned}
$$

and where $\mathrm{E}($.$) denotes the expectations operator.$

The subjective wage $\mathrm{W}$ for household labour is defined as the amount of output a household would require as compensation for a given unit of leisure foregone. This is captured here through the subjective wage rate $\mathrm{w}$ such that total subjective equilibrium labour costs per household are:

$$
\begin{aligned}
\mathrm{W} & =\mathrm{wL} \\
& =\mathrm{wL}_{1}+\mathrm{wL}_{2}
\end{aligned}
$$

These wage costs are affected by the specific household characteristics, which define the dependency ratio and thus the leisure-work trade-off. Total household profits $\Pi$ are defined as revenue net of subjective labour costs:

$$
\Pi \quad=\mathrm{R}-\mathrm{W}
$$

so that expected profits are:

$$
\mathrm{E}(\Pi) \quad=\mathrm{E}(\mathrm{R})-\mathrm{W}
$$

The rate of return $\pi$ of the activity portfolio is then given by:

$$
\begin{aligned}
\pi & =\Pi / \mathrm{R} \\
& =1-(\mathrm{W} / \mathrm{R})
\end{aligned}
$$

where:

$$
\partial \pi / \partial \mathrm{R}>0 \text { and } \partial^{2} \pi / \partial \mathrm{R}^{2}<0
$$


The expected rate of return is thus given by:

$$
\mathrm{E}(\pi) \quad=1-(\mathrm{W} / \mathrm{E}(\mathrm{R}))
$$

The farm household utility function $U$ contains two elements: one representing expected portfolio profits and one representing the expected portfolio risk:

$$
\mathrm{U} \quad=\mathrm{U}(\Pi, \mathrm{V})
$$

where:

$$
\partial \mathrm{U} / \partial \Pi>0, \partial^{2} \mathrm{U} / \partial \Pi^{2}<0, \partial \mathrm{U} / \partial \mathrm{V}<0 \text { and } \partial^{2} \mathrm{U} / \partial \mathrm{V}^{2}>0
$$

Households maximize utility with respect to the labour allocation subject to the labour constraint:

$$
\begin{array}{ll}
\max U & =\mathrm{U}(\Pi, \mathrm{V}) \\
\text { w.r.t. } & \mathrm{q} \\
\text { s.t. } & 0 \leq \mathrm{q} \leq 1
\end{array}
$$

Assuming $\rho=0$ and additive utility, this is solved as follows:

$$
\begin{aligned}
\mathrm{U} & =\mathrm{R}-\mathrm{W}-\mathrm{V} \\
& =\mathrm{p}_{1} \mathrm{a}_{1}-\mathrm{qp}_{1} \mathrm{a}_{1}+q \mathrm{p}_{2} \mathrm{a}_{2}-\mathrm{W}-\mathrm{s}_{1}{ }^{2}+2 \mathrm{qs_{1 }}{ }^{2}-\mathrm{q}^{2} \mathrm{~s}_{1}{ }^{2}-\mathrm{q}^{2} \mathrm{~s}_{2}{ }^{2}
\end{aligned}
$$

where:

$$
\begin{aligned}
& \partial \mathrm{U} / \partial \mathrm{q}=-\mathrm{p}_{1} \mathrm{a}_{1}+\mathrm{p}_{2} \mathrm{a}_{2}+2 \mathrm{~s}_{1}{ }^{2}-2 \mathrm{qs}_{1}{ }^{2}-2 \mathrm{qs}_{2}{ }^{2}=0 \\
& \partial^{2} \mathrm{U} / \partial \mathrm{q}^{2}=-2 \mathrm{~s}_{1}{ }^{2}-2 \mathrm{qs}_{2}{ }^{2}<0
\end{aligned}
$$

so that this utility function, with a negative sign of the risk aversion parameter U',/U', implies risk aversion. Rearranging the first order condition yields:

$$
\begin{aligned}
\mathrm{q} & =-\left(\mathrm{p}_{1} \mathrm{a}_{1}-\mathrm{p}_{2} \mathrm{a}_{2}-2 \mathrm{~s}_{1}{ }^{2}\right) / 2\left(\mathrm{~s}_{2}{ }^{2}-\mathrm{s}_{1}{ }^{2}\right) \\
& \geq 0
\end{aligned}
$$


The numerator of equation 16 is negative and the denominator is positive such that:

$$
\begin{aligned}
& \partial \mathrm{q} / \partial \mathrm{p}_{1}<0, \partial \mathrm{q} / \partial \mathrm{p}_{2}>0, \partial \mathrm{q} / \partial \mathrm{a}_{1}<0, \partial \mathrm{q} / \partial \mathrm{a}_{2}>0 \\
& \partial \mathrm{q} / \partial \mathrm{s}_{1}>0, \partial \mathrm{q} / \partial \mathrm{s}_{2}<0, \partial \mathrm{q} / \partial \mathrm{t}_{1}>0 \text { and } \partial \mathrm{q} / \partial \mathrm{t}_{2}<0
\end{aligned}
$$

Assuming additive utility is non-trivial as a multiplicative functional form would result in a different specification of q:

$$
\begin{array}{ll}
\mathrm{U} & =\Pi / \mathrm{V} \\
\partial \mathrm{U} / \partial \mathrm{q} & =(\partial \Pi / \partial \mathrm{q} \mathrm{V}-\Pi \partial \mathrm{V} / \partial \mathrm{q}) / \mathrm{V}^{2}=0
\end{array}
$$

where the first order condition also includes a term for profits and thus for the subjective wage. This implies that for farm household production in the absence of labour markets and with no riskless activity to engage in, household preferences affect the optimal allocation of resources between risky activities through both the profit and the utility functions. This result does not hold for households facing perfect markets and a riskless investment opportunity. This model differs from standard models of farm production under uncertainty by emphasizing the absence of labour and output markets, the existence of a survival constraint, and the role of the subjective valuation of labour.

Figure 1 summarizes the model where quadrant I plots the profit function (equation 12), quadrant III plots the production function (equation 6), quadrant IV plots the risk function (equation 1) and quadrant II plots the utility function (equation 13) in risk-return space. Quadrant II also summarizes the trade-off between risk and return in the activity portfolio. Households prefer higher expected returns and lower portfolio risk so that $U_{3}>U_{2}>U_{1}$. At point $\mathrm{a}, \mathrm{q}=1$ and the household specializes in activity 2 . At point $\mathrm{d}, \mathrm{q}=0$ and the household 
specializes in activity 1 . At point $\mathrm{c}$, the portfolio has the lowest possible risk $\mathrm{V}_{\min }$ and $\mathrm{q}=$ $\mathrm{q}_{\mathrm{Vmin}}$. Curve abc represents the efficient portfolio frontier.

Equilibrium is obtained at point $b$ where abcd is tangential to the highest possible utility curve $\mathrm{U}_{2}$. The equilibrium level of $\mathrm{q}$ is $\mathrm{q}^{*}$ which is larger than $\mathrm{q}_{\mathrm{Vmin}}$ (figure 1). The household will thus decide at the beginning of the agricultural season to allocate $\mathrm{q}^{*}$ of its labour to activity 2 and $1-\mathrm{q}^{*}$ to activity 1 . The expected shares of revenue from activities 2 and 1 are therefore $\mathrm{q}^{*}$ and $1-\mathrm{q}^{*}$, respectively. Given the high war-related uncertainty, these labour allocation and expected revenue shares are only approximate indicators of the actual output shares per activity at the end of the period. Note that more risk averse households would choose a labour allocation closer to $\mathrm{q}_{\mathrm{Vmin}}$.

\section{War and Coping Strategies}

This section outlines the effects of war on the basic model of activity choices. The nature and the determinants of coping strategies during and after conflict will be discussed.

War has three effects on the risk-risk relationship of the basic model (equation 1). First, the increase in overall risk due to war will shift the whole curve right $\left(\partial \mathrm{V} / \partial \mathrm{s}_{\mathrm{i}}>0\right)$ with the war legacy ensuring that the post-war outcome will still be to the right of the pre-war case (figure 2). Second, the relative changes in risks (say $\Delta \mathrm{s}_{1}{ }^{2} / \Delta \mathrm{s}_{2}{ }^{2}<1$ ) will shift the lower section of the curve even further to the right $\left(\partial \mathrm{V} / \partial \mathrm{s}_{2}=2 \mathrm{q}^{2} \mathrm{~s}_{2}\right)$. With a large $\mathrm{q}$, an increasing $\mathrm{s}_{2}$ leads to a further increase in V. This effect is reduced in the post-war period. Third, the increase in the correlation coefficient flattens the slope near $\mathrm{q}_{\mathrm{Vmin}}\left(\partial(\partial \mathrm{V} / \partial \mathrm{q}) / \partial \mathrm{s}_{12}=2-4 \mathrm{q}\right)$ thus reducing the scope for risk reduction through portfolio diversification. In the post-war period, there is still a higher correlation coefficient though its scale may be lower than during the war. The net effect of the changes is that, during war, the curve abcd shifts down and to the right to an area of 
unambiguously lower utility for the household. In the post-war period, the curve will shift partially back towards the peace-time position (2).

War will change the profit function (equation 9) by affecting revenue and the equilibrium value of the subjective wage, in particular via enforced life-cycle effects in the household. This is most likely to occur through conflict-related morbidity and mortality in the household, especially in households near the survival threshold. If disaster is imminent, then $\mathrm{W}$ will be low and the risk of production and correlation coefficient of returns are likely to be very high, thus reducing the potential gain from diversification. In the post-war period, households may remain in such high risk, near starvation equilibrium, depending how quickly the value of subjective wages can rise under peace conditions. Given strong war effects, many households may exist in the post-war poverty trap in the bottom right corner of quadrant IV in figure 2.

This model can therefore resolve the apparent paradox noted in the safety-first literature where destitute households engage in very risky behaviour even though they are least able to withstand the risks inherent in such a portfolio. It does so by valuing the trade-off between leisure and labour in regard to the survival constraint through the term $\mathrm{W}$, which captures the household consumption requirements.

Household assets and social capital affect the technical efficiency of production and hence $\mathrm{a}_{\mathrm{i}}$. With land abundance and damaged credit markets, assets fulfil a key role as both productive inputs and as a self-insurance mechanism in a risky environment. At the same time, assets are key targets of soldiers and looters. Asset characteristics thus make some activities more vulnerable to war than others. For example, cattle herding may be a productive and a riskmitigating activity in peace-times. Nevertheless, cattle herding becomes unfeasible in a longlasting war of destabilization and may not be worthwhile (due to an expected resumption of 
hostilities) or possible (due to the collapse of cattle markets and extension services) in a high risk, poor post-war environment. Households depend on their land and their social capital for production and social exchange. The portfolio of endowments therefore affects the portfolio of activities undertaken.

The model implies that war-affected households facing substantial market constraints smooth consumption by smoothing income. This result is not obtained in the standard farm household model. Households affected by war hence behave differently from households in peace-time economies. Rural post-war reconstruction policies must support these income smoothing activities while helping to re-establish markets to allow once again consumption smoothing.

War also affects production technologies and relative prices so that both $\mathrm{a}_{\mathrm{i}}$ and $\mathrm{p}_{\mathrm{i}}$ in equations 2 and 4 can be expected to fall. In the case of food crops ( $i=1)$ versus cash crops $(i=2)$, it is also likely that $\Delta \mathrm{a}_{1} / \Delta \mathrm{a}_{2}<1$ and $\Delta \mathrm{p}_{1} / \Delta \mathrm{p}_{2}<1$, as war increases the transaction costs for cash crops relatively more than for food crops and as cash crops have a given world price. In addition, war is likely to enforce the extended use of traditional cropping patterns, seeds and techniques. To the extent that these techniques are more divisible than modern agronomic practices (irrigation being an extreme example of an indivisible modern technique), households adopt a larger number of individual activities within each activity class during the war while reducing the dependence on cash crops. Such traditional techniques include the number of traditional food crops, dividing the cultivated area per household into more but smaller plots and pursuing intensive off-farm activities.

In terms of figure 2 , a proportionate reduction of the parameters $p_{i}$ and $a_{i}$ will shift the $E(R)$ curve to the right in quadrant III. A disproportionately large reduction of the $\mathrm{p}_{2}$ and $\mathrm{a}_{2}$ 
parameters will also reduce the slope of the curve. These war-induced changes in the technology and price variables may only be reversed partially in the post-war period.

Household activity diversification is also encouraged by institutional and market imperfections, which are worsened by war. Such imperfections affect the degree of technology embedded in production $\left(\mathrm{a}_{\mathrm{i}}\right)$ and the farm-gate prices $\left(\mathrm{p}_{\mathrm{i}}\right)$ net of transaction costs $\left(\mathrm{t}_{\mathrm{i}}\right)$. The total labour availability (L) is also shaped by market imperfections, especially through increased search, information and supervision costs in land abundant areas which lead to reduced supply of and demand for labour and hence to the breakdown of wage labour markets. Consequently, the variables $\mathrm{L}, \mathrm{w}$ and $\mathrm{W}$ in equation 8 are shaped by the effects of war on institutions.

Household social capital is a key determinant of the profitability of low-return, off-farm activities, including social exchange and NGO donations. Households with higher social capital (for example households who hold a position of traditional authority in their community) are thus much more likely to command larger labour resources L, have lower transaction costs $t_{i}$ and achieve higher net prices for off-farm activities $\mathrm{p}_{2}$.

Formal and even informal credit markets may cease to exist during war. This is due to the high cost of information gathering, the reduced ability to enforce contracts while state authority is so severely threatened and the high degree of risk covariance which increases the undiversifiable portfolio risk for lenders. Credit-constrained households are thus likely to increase their share of informal, social, non-market activities to substitute for war-affected credit markets.

Given the reduced number of feasible choices under war conditions, there is an externality effect of household market withdrawal. At the margin, one more household reducing its market participation will prevent all other households from joining a market. This effect is 
particularly pronounced if households' transaction costs are uniformly affected by the war, creating a high covariance of risks, and covariant household activity choices. This is a further reason for market breakdown in war conditions.

Volatile markets increase the incentives for households to engage in subsistence activities. "Village enclaves" (Dasgupta 1993: p. 235) are more pronounced in a post-war environment and location will be a strong determinant of household behaviour. In the extreme, these effects may create village-level poverty traps, from which no individual household can endogenously free itself.

\section{The Case of Mozambique}

Rural Mozambique provides a suitable case study for war-affected coping strategies as it experienced a devastating civil war until 1992. For example, the number of cattle in Mozambique declined from over 1.3 million in 1982 to 0.25 million in 1992 (Ministério da Agricultura 1994). Farm productivity in the post-war period continued to remain well below regional averages (Tschirley and Weber 1994) while per capita food production only reached 90 percent of its pre-war level by 1996 (World Bank 2002). In 1995, gross domestic product per capita was only 146 US dollars (World Bank 2002) and in the Human Development Index Mozambique ranked among the ten least developed countries in the world (UNDP 1999).

The north of Mozambique is often considered the "green belt" of the country. However, postwar agricultural production was hampered by poor transport networks and the absence of irrigation infrastructure and of mechanized agricultural production. There were few agricultural or non-agricultural employment opportunities, no migrant workers and no formal credit markets. 
The farm household survey used for this analysis includes 371 randomly selected households in 16 villages (the primary sampling units, PSU) in three districts in Nampula and Cabo Delgado provinces in northern Mozambique (MAP/MSU Research Team 1996). The findings of the survey are broadly representative of the more accessible parts of northern Mozambique. The sample was stratified according to households' cotton growing status. The survey data, here denoted FSP, was collected by the Food Security Project at the Ministry of Agriculture, Maputo, from June 1994 to January 1996. All variables below will refer to the year 1995 unless stated otherwise. The variables are summarized in table 1. The FSP survey is one of the most carefully designed, collected, and cleaned rural household surveys from the early postwar period in Mozambique. The evidence provided by the FSP survey is complemented by qualitative data collected during two visits to northern Mozambique in 1995 and 1999.

\section{Specification Issues}

Equation 16 defines the functional form for $\mathrm{q}$ as:

$$
\mathrm{q}=\quad-\left(\mathrm{p}_{1} \mathrm{a}_{1}-\mathrm{p}_{2} \mathrm{a}_{2}-2 \mathrm{~s}_{1}^{2}\right) / 2\left(\mathrm{~s}_{2}^{2}-\mathrm{s}_{1}^{2}\right)
$$

where $\mathrm{q}$ must lie in the interval 0 to 1 . The equilibrium determinants of $\mathrm{q}$ are thus closely related to the independent parameters $\mathrm{p}_{\mathrm{i}}, \mathrm{a}_{\mathrm{i}}$ and $\mathrm{s}_{\mathrm{i}}{ }^{2}$. Depending on the functional form of the utility function, $\mathrm{q}$ also depends on $\rho_{\mathrm{ij}}$ and $\mathrm{W}$. This implies that subjective wages and household endowments matter for activity choices. Furthermore, war requires controlling for the subjective valuation of leisure and household- and village-level transaction costs (equation $5)$.

Taking $\mathrm{q}$ as a general indicator of activity choices and replacing the model parameters $\mathrm{p}_{\mathrm{i}}, \mathrm{a}_{\mathrm{i}}$, $\mathrm{s}_{\mathrm{i}}{ }^{2}, \rho_{\mathrm{ij}}$, and $\mathrm{W}$ with corresponding household survey indicators thus yields the reduced-form equation: 


$$
\mathrm{q}_{\mathrm{i}} \quad=\quad \alpha_{0}+\alpha_{1} \mathbf{L}_{\mathrm{i}}+\alpha_{2} \mathbf{F}_{\mathrm{i}}+\alpha_{3} \mathbf{K}_{\mathrm{i}}+\alpha_{4} \mathbf{V}+\mathrm{e}_{\mathrm{i}}
$$

where $\mathbf{L}_{\mathrm{i}}, \mathbf{F}_{\mathrm{i}}, \mathbf{K}_{\mathrm{i}}$, and $\mathbf{V}$ are vectors representing labour, field, capital endowments and villagelevel characteristics, respectively, and where $e_{i}$ is an error term which is not correlated with the exogenous variables thus yielding unbiased and consistent estimates for the vectors of coefficients $\alpha_{h}$ for households $i=1 \ldots N$ and groups of coefficients $\alpha_{h}$ for $h=0 \ldots 4$.

Equation 18 is not restricted to a specific functional form and may thus be guided by theoretical considerations, practical experience and statistical tests. A priori considerations and experience suggest mainly linear, log-linear and quadratic forms for the independent vectors $\mathbf{L}_{\mathrm{i}}, \mathbf{F}_{\mathrm{i}}, \mathbf{K}_{\mathrm{i}}$, and $\mathbf{V}$. This specification thus corresponds closely to those used in the literature on household income diversification (for example by Reardon et al 1992).

Some of the decisions, for example to participate in markets or to adopt cotton, are discrete choices which cannot be modelled with the linear approach. Instead, assume that a household participates in a market if it considers it to be a profitable move such that:

$$
\begin{aligned}
& \mathrm{q}_{\mathrm{i}}=1 \text { if } \pi_{\mathrm{i}}>0 \\
& \mathrm{q}_{\mathrm{i}}=0 \text { otherwise }
\end{aligned}
$$

where $\pi_{\mathrm{i}}$ is the expected rate of profitability of market participation for household $i=1 \ldots \mathrm{N}$. Furthermore, assume that the profitability of the activity is determined by a model akin to that of equation 18 . The binary model to be estimated is then:

$$
\begin{aligned}
& \operatorname{Prob}\left(\mathrm{q}_{\mathrm{i}}=1\right)= \\
& \mathrm{F}\left(\alpha_{0}+\alpha_{1} \mathbf{L}_{\mathrm{i}}+\alpha_{2} \mathbf{F}_{\mathrm{i}}+\alpha_{3} \mathbf{K}_{\mathrm{i}}+\alpha_{4} \mathbf{V}\right)
\end{aligned}
$$

where $\mathrm{F}$ is a cumulative probability function closely related to equation 18 . This model can be estimated by logit or probit, if the error term follows a logistic or normal distribution, respectively. Such a model thus estimates the probability that a household undertakes a certain 
activity given the household's endowments, preferences and the prevailing prices. Following Cramer and Ridder (1991), a binary (not a multiple-category) variable was adopted for this analysis to capture the essential difference between no market participation on the one hand and some form of market participation on the other hand.

One interpretation of $\mathrm{q}$ in equation 18 is as the share of net household income from agricultural activities (SHAREON). The share of subsistence (i.e. non-market) income is denoted $1-\mathrm{q}$ (and captured by the variable SHARESUB) and the share of market income is denoted q. The categorical variable STATUS3 identifies households which have some degree of crop market participation. Other variables break output market participation down into subgroups such as "selling food crops only", "selling cash crops only" and "selling food and cash crops" (STATUS2), where cash crops are defined as inedible crops. The categorical variable COTTON measures whether households plant any cotton at all, which implies $q>0$ in the model above.

One non-monetary and non-market indicator of household diversification is PLOTFRAG, which measures the degree of spatial diversification of farm households or farm fragmentation. Formally, PLOTFRAG is defined as the natural $\log$ of the weighted Herfindahl-Hirschman Index (HHI) of plot diversification:

$$
\mathrm{HHI}=1 /\left(\sum \mathrm{q}_{\mathrm{i}}{ }^{2}\right), \mathrm{i}=1 \ldots \mathrm{N}
$$

where $\mathrm{q}_{\mathrm{i}}$ is the share of plot $\mathrm{i}$ 's area of the total cultivated area per household and $\mathrm{N}$ is the total number of plots farmed per household. The HHI is weighted by the area cultivated per household to allow comparisons across households irrespective of farm size. PLOTFRAG is almost normally distributed. 
Another measure of non-market diversification is the degree of social exchange (EXCHANGE). This is defined as the natural $\log$ of the sum of the absolute value of remittances and social exchange both given and received between January and September 1995 (the data for the remaining three months of 1995 is incomplete). EXCHANGE measures the sum of the absolute values as the actual flows given and received may cancel out, which would underestimate the degree of social exchange.

\section{Results and Discussion}

This section will describe and discuss some of the key findings of the empirical analysis. Given the large number of regressions presented, the discussion will have to be very selective.

\section{Summary Statistics}

Households are very dependent on subsistence food crop activities for their income, with cash crops contributing only a small share to total income but three quarters of all crop marketing income (table 2). Entrepreneurial, wage and social income account for even smaller shares of household income. The high shares of on-farm income (SHAREON) and non-market income (SHARESUB) of total income suggest that households in northern Mozambique in 1995 were still practicing many of their war-time subsistence coping strategies.

Table 3 compares these findings to those from 28 other farm surveys from Sub-Saharan African countries, which report lower on-farm and higher off-farm income shares. Interestingly, the share of social income is also higher in the other surveys, suggesting that war may also reduce a household's capacity to generate social income. Other authors report household income shares from off-farm activities in African countries of between $30 \%$ and 50\% occasionally reaching 90\% (Ellis 1998, Reardon 1997, von Braun and Pandya-Lorch 
1991). It is thus apparent that the share of off-farm income in the post-war FSP survey is particularly low.

Household output market participation decisions were very flexible in post-war northern Mozambique (table 4). The FSP survey recorded crop sales for the two agricultural years ending 1994 and 1995. 43\% of all households did not change their market participation status between 1994 and 1996, 20\% of all households either added another type of crop or specialized in cash crops and $38 \%$ reduced the number of types of crops sold or even resumed a pure subsistence status. In fact, the total share of households marketing some cash crops dropped from $63 \%$ to $54 \%$ while the share of pure subsistence households increased from $13 \%$ to $21 \%$ in one year. These figures show that households adjust their market participation in the face of a variety of changing constraints from year to year and that households differentiate their market participation decisions between food crop and cash crop markets.

\section{Degree of On-Farm Activities}

The SHAREON regression (table 5a) is highly significant and has a good fit with an $\mathrm{R}^{2}$ value of 0.59 . The positive coefficient of ANIMAL suggests that having more livestock helps to increase agricultural income activities. This may be related to the synergies derived from livestock ownership (especially in the post-war absence of commercial farm inputs like fertilizers).

The social capital variables are entirely insignificant. This is slightly surprising as investments in social institutions could be a key response by households to high post-war levels of uncertainty. Their insignificance may derive from three sources. First, the share of social income in total income is very small thus reducing the role of social institutions in explaining income shares. Second, social institutions may be less important than anticipated if their 
determinants are equal to those of market activities. In that case, market and social exchange are not substitutes but complements. Third, the proxies for social institutions included in the FSP survey may only measure such institutions imperfectly.

\section{Autarky versus Crop Market Participation}

The STATUS3 regression (table $5 b$ ) is highly significant. One village indicator variable was dropped, as that location predicted crop market participation perfectly, and 21 observations were not used.

Households with a higher dependency ratio have a strongly reduced probability of crop market participation, indicating household-specific propensity to participate in crop markets. A higher household human capital increases market participation (EDUMAX, EDUMAXSQU). In a review of recent evidence on the effects of education in the rural economy, a similar effect of education was noted (Taylor and Yunez-Naude 2000). There appears to be no link from education to farm output but a link from education to farm activity choices in Africa.

Total farm size in 1994-95 (AREATOTAL) is a highly significant factor. This result implies that there are fixed transaction costs of market participation. Households with larger land endowments may have a comparative advantage in farming, lower transaction costs of land acquisition or market imperfections can be better internalised by larger scale farms. Strongly war-affected households may thus be doubly constrained in their reconstruction efforts. First they have less land for farming and second they have less access to crop markets, with the former effect reinforcing the latter.

The probability of crop market participation is reduced by owning more agricultural tools per household (TOOL) and increased by owning a larger range of agricultural tools (TOOLTYPE). The ownership of livestock at the end of the war (ANIMAL) is a positive 
determinant of current crop market activity. Households which had been subjected to asset destruction during the war were thus damaged in their ability to rejoin crop markets for many years to come even after the cessation of violence.

\section{Degree of Subsistence Activity}

The SHARESUB regression (table $5 \mathrm{c}$ ) is highly significant and has a good fit with an $\mathrm{R}^{2}$ of 0.46. A variance inflation factor (VIF) analysis does not suggest a presence of significant multicollinearity. The determinants of the degree of market participation (SHARESUB) differ significantly from those for the basic decision of whether to participate in any markets at all (STATUS3). For instance, the scale effect operates through household size, and hence lifecycle effects, and not through farm size. Female-headed households, whose market participation does not differ systematically from that of other households, on average have a share of subsistence income 11 percentage points higher than other households (FEMHEAD). Female-headed households enter crop markets like other households but their share of marketbased income in total income is much lower.

Environmental and social risks induce households to engage more in market activities, probably because those risks are less correlated with market risks and thus offer scope for risk diversification. Social and village level variables also strongly affect household market participation decisions. It is likely that the war increased the importance of these factors and that they will only slowly diminish in importance in the post-war northern Mozambican context.

\section{Cash Crop Adoption}

The logit regression of COTTON (table 5d) is significant with a p-value of 0.011. Educational variables (EDUMUM, EDUMUMSQU) are not significant determinants of cash crop 
adoption. A Ugandan farm household study found a similar absence of educational achievements on crop adoption (Appleton and Balihuta 1996). That study also analysed a post-war economy, suggesting that the adoption effects of education are more limited when general economic circumstances are unfavourable for growth and poverty alleviation.

Instead, the adoption of cotton in the post-war period in northern Mozambique is shaped by the household composition, availability and valuation of labour, by alternative investment opportunities and returns, and by comparative advantage as determined by local climatic and institutional conditions. The risk attitude and risk bearing capacity of households determine if households are willing to adopt cotton. Female-headed and local political status, for example, almost perfectly predict cotton adoption for almost $10 \%$ of the sample. A significant lifecycle effect occurs through the mean age of the household (AGEHH, AGEHHSQU). The war affects household cash crop decisions indirectly through the subjective value households attach to their labour, which are in part determined by a household's experience of the recent war. These indirect effects of war are very difficult for public policy to remove and it is likely that such differences will persist over a long time.

\section{Plot Diversification}

The determinants of PLOTFRAG are shown in table 5e. The regression is highly significant, has a reasonable fit with an $\mathrm{R}^{2}$ of 0.39 and has no apparent problem of multicollinearity as determined by VIF analysis. Given the significance of gender and household size coefficients, the household labour constraint is an important determinant of plot diversification. This finding is supported by interview evidence with agronomists in northern Mozambique. These interviews confirmed that planting fields benefited from being done quickly to utilize the best "window of opportunity" appropriate for that field. With more but smaller fields, households can spread these points in time and thus manage a larger cultivated area with a given amount 
of labour. These results confirm the hypothesis that households in the post-war period react strongly to some types of risks by altering their non-market production behaviour.

Plot diversification is also a response to life cycle effects and household endowments, with gender having a strong effect on plot diversification. Household assets reduce such diversification while some soil characteristics and social capital have less importance. Finally, market opportunities help reduce spatial diversification while market risks increase it. Households which are emerging from a position of war-induced isolation are thus clearly using non-market diversification strategies.

\section{Social Exchange}

The EXCHANGE regression (table 5f) is highly significant and has a reasonable fit with an $\mathrm{R}^{2}$ value of 0.37 . A VIF analysis does not suggest the presence of multicollinearity. The result also appears robust to the omission of the zero-exchange households. Having many women (FEMALE, FEMALESQU) or men (MALE, MALESQU) in the household increases social exchange though both effects are quadratic with minima at 4.0 and 2.7 persons, respectively. This confirms the possible dependence of rural social networks in Mozambique on very large families (Garrett and Ruel 1999).

Likewise, intergenerational dependence is a strong determining factor for informal social security mechanisms, with younger and older household heads (AGEHEAD, AGEHEADSQU) being more involved in transfers. The significant effects of the mean household age (AGEHH, AGEHHSQU) could represent the accumulation of contacts, a form of social capital, which is necessary in conducting exchange.

Better asset-endowed households can afford more insurance while also being more capable of utilizing self-insurance mechanisms. Social exchange thus appears to be an insurance 
mechanism for better-off households. Households in which the husband comes from the local village (ORIGINMAN) have much lower social exchange than other households. Therefore, the move of husbands to the village of their wife sometime after their wedding, as is common practice in northern Mozambique, helps to build long-distance sources of remittance and social income. This tradition should help to overcome the correlation of income within small areas.

\section{Conclusions}

This section summarizes the main results from the empirical analysis and their implications for the theory of post-war coping strategies and post-war reconstruction policy.

First, it was found that post-war coping strategies include many different market and nonmarket activities. The war forced households to specialize in on-farm, subsistence activities. In the post-war period, households are diversifying their activities as a response to the varying war legacy and to emerging peace-time opportunities. Post-war behaviour exhibits a surprisingly high degree of variance across activities. Particularly market participation rates fluctuate strongly across households and seasons.

Second, determinants of post-war diversification are primarily the indirect war effects which include risk (as expected) but also household life cycle position, household endowments and transaction costs at the household and village levels. The strong role of life cycle effects indicates the importance of land abundance for the study of war-affected African farm households (Binswanger and McIntire 1987), especially via the negative effect of war on the marginal value of effort. The estimated determinants are consistent with the model proposed initially. They indicate a stronger emphasis on household and village characteristics in the determination of activity choices than standard farm household models would have suggested. 
Third, households may become risk takers near the absolute survival threshold by specializing in fewer activities and completely reducing their asset base to survive into the next season. This is primarily the result of the war-induced destruction of many alternative activity options such as asset endowments and markets and the subsequent fall of many households into various poverty traps. Even if conditions improve after the war, households suffer long-term consequences of having previously faced starvation. That is, past events and choices have strong effects on future outcomes for poor, war-affected farm households.

Fourth, there is a difference between the determinants of a categorical decision to participate in output markets and the determinants of the continuous degree of market participation. The former is more affected by household life cycle, endowment and scale effects while the latter is strongly affected by the household risk experiences, social capital and village level variables. For instance, female-headed households have the same market participation pattern but a smaller market income share than male-headed households. This pattern may extend to cash crop adoption though the data was insufficient to study the degree of cash crop adoption distinctly from the decision to adopt cash crops.

Fifth, social activities are more useful for households which face only commodity-specific market failure. For households facing market failure across a whole range of products and services, i.e. for economically isolated or almost autarkic households, social contacts may not offer a significant alternative income source in the post-war, rural context.

Sixth, farm households practice various non-market forms of activity diversification and these can be expected to be important during the war. The regression analysis focused on spatial diversification and social exchange as two such examples. Surprisingly, social exchange is quite limited after the war, in part due to the widespread absolute poverty in the sample area. 
Its determinants are similar to those of output market participation. Social exchange is thus no alternative to market participation for the poorest and most war-affected households.

Seventh, village level effects were found to be extremely important determinants of coping strategies. From a policy perspective, this implies that the government and donors can assist household coping strategies by providing public goods to enhance market participation and diversification opportunities. Post-war public policy must recognize the importance of local differences in the experience of war. Reconstruction policy must hence prioritise assistance depending on the local war legacy.

Finally, other important determinants of post-war coping strategies include household labour characteristics, asset endowments, farm size and social capital. Reconstruction policy should therefore aim to re-capitalize war-affected households, enhance human capital and reduce rural transaction costs to affect the whole range of diversification determinants. Lowering war-induced transaction costs will have strong positive effects on the market participation and off-farm earnings of agricultural households. 
Figure 1: The Two-Activity Farm Household Model

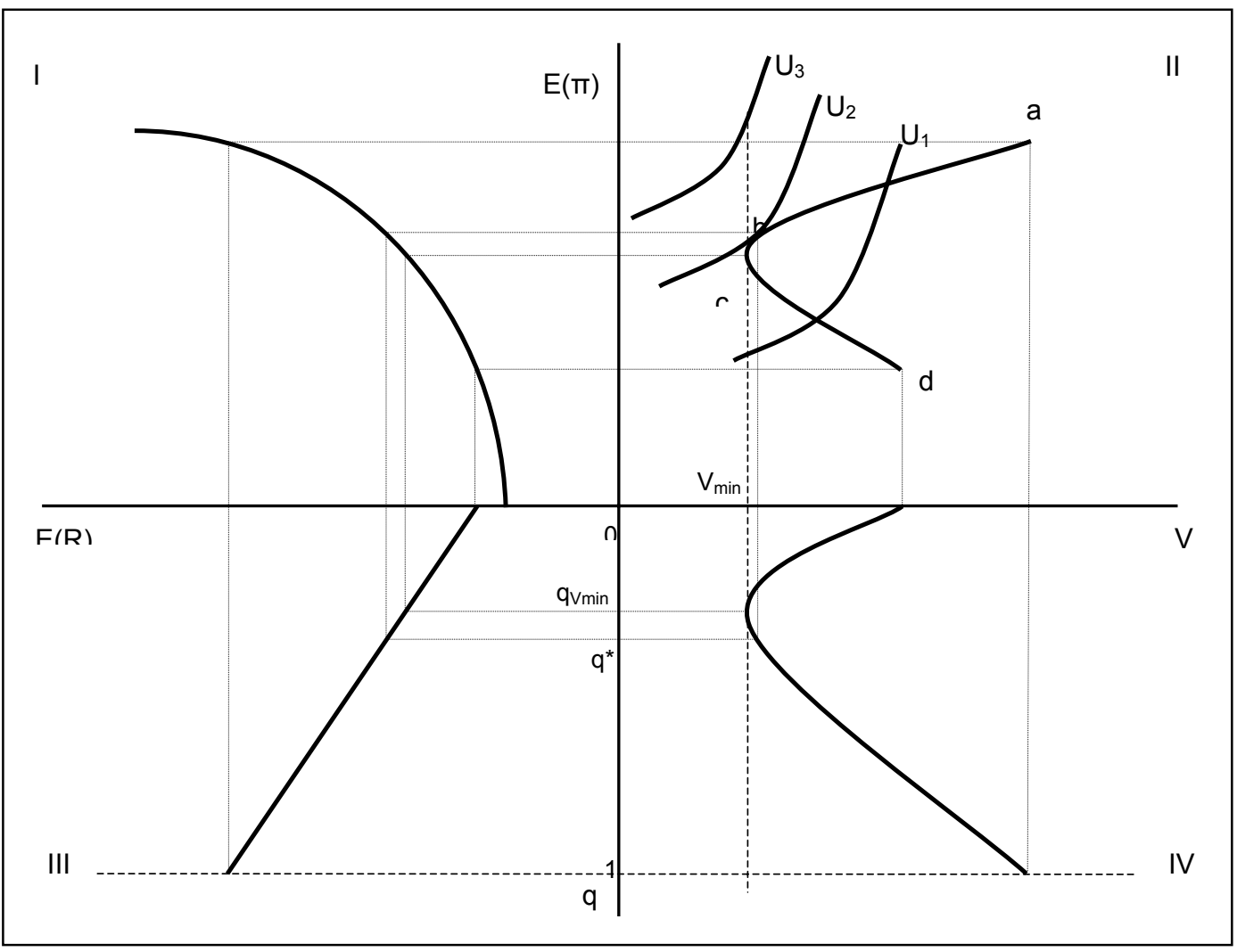

Figure 2: The Effects of War in the Two-Activity Farm Household Model

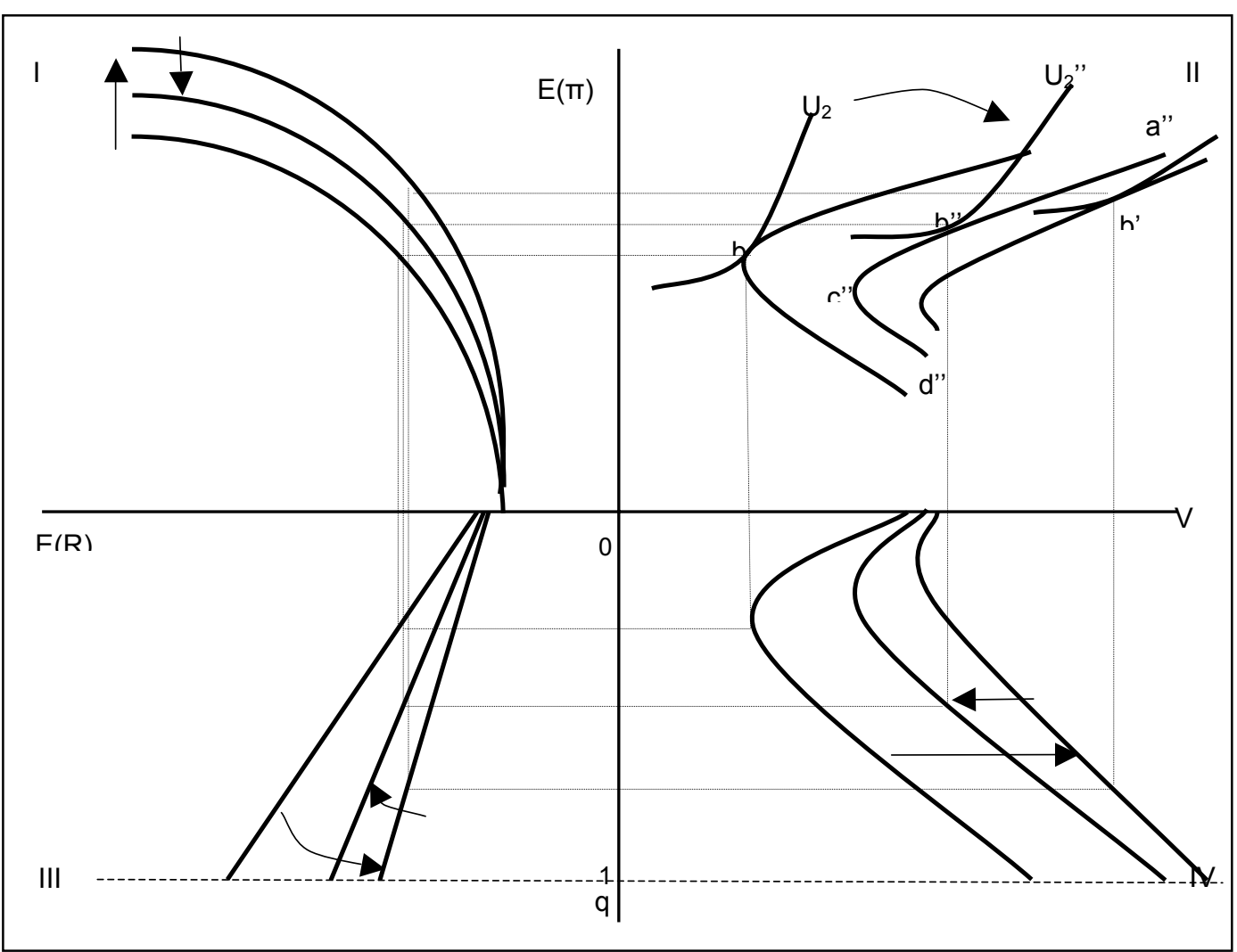


Table 1: The Variables of the FSP Survey

\begin{tabular}{|c|c|c|c|c|c|}
\hline Name & Definition & Mean & St Err & Min & Max \\
\hline \multicolumn{6}{|l|}{ Activity Variables } \\
\hline COTTON & Does this household grow cotton in 1995 & 0.505 & 0.062 & c & 1 \\
\hline EXCHANGE & $\begin{array}{l}\text { Natural log of the total } \$ \text { value of remittances and gifts given and } \\
\text { received per capita per household January till September } 1995\end{array}$ & 0.003 & 0.066 & -4.026 & 3.006 \\
\hline INCOME & Net household income in \$ in 1995 & 250.964 & 23.689 & 19.941 & $6,495.847$ \\
\hline INCOMEPC & Net household income per capita in \$ in 1995 & 37.130 & 3.609 & 4.500 & 463.989 \\
\hline PLOTFRAG & $\begin{array}{l}\text { Natural log of the effective number of plots per hectare per } \\
\text { household in } 1995\end{array}$ & 0.381 & 0.037 & -2.507 & 3.567 \\
\hline SHAREON & $\begin{array}{l}\text { Share of income derived from food and cash crops in \% per } \\
\text { household }\end{array}$ & 0.821 & 0.018 & 0.180 & 1 \\
\hline SHARESUB & $\begin{array}{l}\text { Share of income derived from subsistence activities per } \\
\text { household in } 1995\end{array}$ & 0.607 & 0.027 & 0.005 & 1 \\
\hline STATUS1 & Type of household by output market participation in 1993-94 & 2.860 & 0.096 & 1 & 4 \\
\hline STATUS2 & Type of household by output market participation in $1994-95$ & 2.544 & 0.182 & 1 & 4 \\
\hline STATUS3 & Type of household by crop market participation in 1994-95 & 0.786 & 0.055 & 0 & 1 \\
\hline TYPE1 & $\begin{array}{l}\text { Which type of income activities is the household undertaking in } \\
1995 ?\end{array}$ & 2.860 & 0.106 & 1 & 4 \\
\hline TYPE2 & Household is participating in off-farm activities in $1995 ?$ & 0.438 & 0.049 & $\mathrm{c}$ & 1 \\
\hline \multicolumn{6}{|l|}{ Labour Variables } \\
\hline$\overline{A D U L T}$ & Number of non-dependent residents per household in mid-1995 & 5.573 & 0.330 & 1 & 15 \\
\hline ADULTSQU & $\begin{array}{l}\text { Square of number of non-dependent residents per household in } \\
\text { mid-1995 }\end{array}$ & 37.262 & 4.266 & 1 & 225 \\
\hline AGEHEAD & Age of household head in years in mid-1995 & 40.928 & 1.354 & 19 & 83 \\
\hline AGEHEADSQU & Square of age of household head in years in mid-1995 & $1,830.025$ & 111.895 & 361 & 6,889 \\
\hline AGEHH & Average age of household in years in early 1995 & 22.124 & 0.100 & 8.750 & 69 \\
\hline AGEHHSQU & Square of average age of household in years in early 1995 & 548.877 & 48.504 & 76.563 & 4.761 \\
\hline DEPEND & Number of dependent residents per household in mid-1995 & 1.888 & 0.111 & 0 & 7 \\
\hline DEPENDRATIO & Dependency ratio per household in mid-1994 & 0.275 & 0.016 & $\mathrm{c}$ & 1 \\
\hline DEPENDSQU & $\begin{array}{l}\text { Square of number of dependent residents per household in mid- } \\
1995\end{array}$ & 5.534 & 0.523 & $\mathrm{c}$ & 49 \\
\hline EDUHH & $\begin{array}{l}\text { Average number of years of education per household member in } \\
\text { mid-1994 }\end{array}$ & 0.964 & 0.061 & $\mathrm{c}$ & 4 \\
\hline EDUHHSQU & $\begin{array}{l}\text { Square of average number of years of education per household } \\
\text { member in mid-1994 }\end{array}$ & 1.510 & 0.163 & c & 16 \\
\hline EDUMAX & Maximal number of years of effective education per household & 3.582 & 0.213 & $\mathrm{c}$ & 12 \\
\hline EDUMAXSQU & $\begin{array}{l}\text { Square of maximal number of years of effective education per } \\
\text { household }\end{array}$ & 17.625 & 1.453 & $\mathrm{c}$ & 144 \\
\hline EDUMUM & Number of years of education of the mother per household & 0.774 & 0.159 & 0 & 7 \\
\hline EDUMUMSQU & $\begin{array}{l}\text { Square of number of years of education of the mother per } \\
\text { household }\end{array}$ & 2.333 & 0.556 & c & 49 \\
\hline FEMALE & Number of females per household in 1994-96 & 3.472 & 0.198 & 0 & 10 \\
\hline FEMALESQU & Square of number of females per household in $1994-96$ & 15.219 & 1.682 & $\mathrm{c}$ & 100 \\
\hline FEMHEAD & Was this a female-headed household in mid- $1994 ?$ & 0.013 & 0.006 & $c$ & 1 \\
\hline ILLNOW & Total number days ill per household in 1995-96 & 21.772 & 2.351 & $\mathrm{c}$ & 215 \\
\hline ILLPAST & Total number days ill per household in 1994-95 & 46.066 & 10.599 & 0 & 433 \\
\hline MALE & Number of males per household in $1994-96$ & 3.956 & 0.183 & $c$ & 11 \\
\hline MALESQU & Square of number of males per household in 1994-96 & 19.638 & 1.673 & 0 & 121 \\
\hline TIMEHARVEST & $\begin{array}{l}\text { Number of hours per month the wife spent collecting water in the } \\
\text { harvest season in } 1995\end{array}$ & 24.629 & 3.274 & $\mathrm{c}$ & 270 \\
\hline TIMEHUNGRY & $\begin{array}{l}\text { Number of hours per month the wife spent collecting water in the } \\
\text { hungry season in } 1995\end{array}$ & 15.060 & 1.001 & $\mathrm{c}$ & 60 \\
\hline \multicolumn{6}{|l|}{ Land Variables } \\
\hline AREALOG & $\begin{array}{l}\text { Natural log of cultivated area per capita in 1994-95 per } \\
\text { household in hectare }\end{array}$ & -1.033 & 0.089 & -3.337 & 1.065 \\
\hline AREATOTAL & $\begin{array}{l}\text { Cultivated and fall area per capita per household in 1994-95 in } \\
\text { hectare }\end{array}$ & 4.023 & 0.254 & 0.290 & 35 \\
\hline AREATOTALLOG & $\begin{array}{l}\text { Natural log of cultivated and fall area per capita in } 1994-95 \text { per } \\
\text { household in hectare }\end{array}$ & -0.681 & 0.084 & -2.773 & 1.131 \\
\hline DISTANCE & Distance to fields in minutes in 1995 per household & 40.669 & 3.481 & 2 & 188.571 \\
\hline DISTANCESQU & Square of distance to fields in minutes in 1995 per household & $2,312.797$ & 324.291 & & $35,559.180$ \\
\hline PESTHIGH & $\begin{array}{l}\text { Do more than } 75 \% \text { of all types of stored food crops suffer from } \\
\text { pests? }\end{array}$ & 0.459 & 0.041 & $\mathrm{c}$ & 4 \\
\hline PESTLOW & $\begin{array}{l}\text { Do more than } 25 \% \text { of all types of stored food crops suffer from } \\
\text { pests? }\end{array}$ & 0.754 & 0.043 & c & 1 \\
\hline PESTMEDIUM & $\begin{array}{l}\text { Do more than } 50 \% \text { of all types of stored food crops suffer from } \\
\text { pests? }\end{array}$ & 0.593 & 0.049 & $\mathrm{c}$ & 1 \\
\hline RAIN & $\begin{array}{l}\text { Proportion of cultivated area per household with lack of rain in } \\
1994-95\end{array}$ & 0.296 & 0.049 & $\mathrm{c}$ & 1 \\
\hline SOILBAD & Very low soil quality per household? & 0.286 & 0.047 & $\mathrm{c}$ & 1 \\
\hline SOILGOOD & Very high soil quality per household? & 0.408 & 0.053 & c & 1 \\
\hline TENURE & Are you worried about household land tenure? & 0.522 & 0.075 & 0 & \\
\hline
\end{tabular}




\begin{tabular}{|c|c|c|c|c|c|}
\hline ANCESTOR & Does the household have ancestors who were buried locally? & 0.844 & 0.041 & 0 & 1 \\
\hline ANIMAL & Household owns at least one large animal in late $1992 ?$ & 0.112 & 0.027 & 0 & 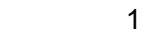 \\
\hline ASSET & Value of assets in real 1996 US\$ per household in late 1992 & 166.802 & 23.127 & 0 & $2,471.327$ \\
\hline ASSETLOG & $\begin{array}{l}\text { Natural log of value of assets in real } 1996 \text { US } \$ \text { per household in } \\
\text { late } 1992\end{array}$ & 2.925 & 0.254 & 0 & 7.813 \\
\hline AUTHORITY & $\begin{array}{l}\text { Is household head in any position of traditional or political } \\
\text { authority? }\end{array}$ & 0.071 & 0.013 & 0 & 1 \\
\hline DONATION & Has this household received food, seed or in-kind aid? & 0.079 & 0.027 & 0 & \\
\hline ORIGINMAN & Is this village the origin of the main man in the household? & 0.678 & 0.049 & 0 & \\
\hline ORIGINWOMAN & Is this village the origin of the main woman in the household? & 0.652 & 0.050 & 0 & \\
\hline TOOL & Number tools per household in mid-1995 & 6.175 & 0.242 & 0 & 27 \\
\hline TOOLPC & Number tools per capita per household in mid-1995 & 0.926 & 0.063 & 0 & 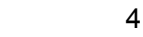 \\
\hline TOOLTYPE & Number of types of tools per household in mid-1995 & 2.899 & 0.115 & 0 & \\
\hline \multicolumn{6}{|l|}{ Village Variables } \\
\hline INFRASTR & $\begin{array}{l}\text { Above average complaints about economic infrastructure and } \\
\text { trade per village }\end{array}$ & 0.451 & 0.122 & 0 & 1 \\
\hline LABOR & $\begin{array}{l}\text { Natural log of the number of hours of labour hired for farm work } \\
\text { per village in } 1995\end{array}$ & 7.234 & 0.188 & 5.236 & 9.680 \\
\hline LABORPC & $\begin{array}{l}\text { Natural log of the number of hours of labour hired per capita for } \\
\text { farm work per village in } 1995\end{array}$ & 1.402 & 0.184 & 0.325 & 3.399 \\
\hline MARKET & Total crop sales by all village households in $\$$ in $1993-94$ & $3,564.409$ & 572.805 & 525.158 & $13,398.710$ \\
\hline MARKETLOG & $\begin{array}{l}\text { Natural log of total crop sales by all village households in } \$ \text { in } \\
1993-94\end{array}$ & 7.531 & 0.231 & 4.987 & 10.044 \\
\hline MILL & Number of mills near household in mid-1995 & 2.242 & 0.308 & 1 & 15 \\
\hline YIELDCOTTON & $\begin{array}{l}\text { Natural log of mean yield for cotton per village in } \mathrm{kg} \text { per ha in } \\
1994-95\end{array}$ & 6.351 & 0.134 & 4.934 & 7.249 \\
\hline YIELDMAIZE & $\begin{array}{l}\text { Natural log of mean yield for maize per village in } \mathrm{kg} \text { per ha in } \\
1994-95\end{array}$ & 5.609 & 0.113 & 4.895 & 6.989 \\
\hline \multicolumn{6}{|l|}{ Control Variables } \\
\hline PRICE14 & $\begin{array}{l}\text { Paasche price index for purchased food in late } 1995 \text { per } \\
\text { household }\end{array}$ & 0.929 & 0.036 & 0.297 & 2.587 \\
\hline PRICE15 & $\begin{array}{l}\text { Paasche price index for purchased food in early } 1996 \text { per } \\
\text { household }\end{array}$ & 1.128 & 0.073 & 0.333 & 3.554 \\
\hline PRICE23 & $\begin{array}{l}\text { Paasche price index for purchased non-food in mid-1995 per } \\
\text { household }\end{array}$ & 1.050 & 0.059 & 0.510 & 2.420 \\
\hline PRICE24 & $\begin{array}{l}\text { Paasche price index for purchased non-food in late } 1995 \text { per } \\
\text { household }\end{array}$ & 0.978 & 0.051 & 0.399 & 3.212 \\
\hline PRICE33 & $\begin{array}{l}\text { Paasche price index home produced food crops in mid-1995 per } \\
\text { household }\end{array}$ & 1.044 & 0.066 & 0.456 & 2.736 \\
\hline PRICE34 & $\begin{array}{l}\text { Paasche price index home produced food crops in late } 1995 \text { per } \\
\text { household }\end{array}$ & 1.096 & 0.152 & 0.375 & 2.473 \\
\hline PRICE35 & $\begin{array}{l}\text { Paasche price index home produced food crops in early } 1996 \\
\text { per household }\end{array}$ & 1.299 & 0.208 & 0.382 & 2.618 \\
\hline PRICEV1 & Variance of PRICE1X & 0.090 & 0.015 & 0.000 & 1.784 \\
\hline PRICEV2 & Variance of PRICE2X & 0.058 & 0.013 & 0.000 & 1.412 \\
\hline PRICEV3 & Variance of PRICE3X & 0.403 & 0.110 & 0.000 & 1.335 \\
\hline VILLAGE111 & Does this household live in village $111 ?$ & 0.042 & 0.030 & 0 & \\
\hline VILLAGE112 & Does this household live in village $112 ?$ & 0.042 & 0.034 & 0 & \\
\hline VILLAGE113 & Does this household live in village $113 ?$ & 0.039 & 0.028 & 0 & 1 \\
\hline VILLAGE114 & Does this household live in village $114 ?$ & 0.022 & 0.018 & 0 & \\
\hline VILLAGE121 & Does this household live in village $121 ?$ & 0.104 & 0.091 & 0 & \\
\hline VILLAGE122 & Does this household live in village $122 ?$ & 0.084 & 0.076 & 0 & 1 \\
\hline VILLAGE123 & Does this household live in village $123 ?$ & 0.169 & 0.118 & 0 & 4 \\
\hline VILLAGE214 & Does this household live in village $214 ?$ & 0.047 & 0.034 & 0 & \\
\hline VILLAGE215 & Does this household live in village $215 ?$ & 0.034 & 0.029 & 0 & I \\
\hline VILLAGE221 & Does this household live in village $221 ?$ & 0.042 & 0.033 & 0 & \\
\hline VILLAGE231 & Does this household live in village $231 ?$ & 0.035 & 0.032 & 0 & \\
\hline VILLAGE232 & Does this household live in village $232 ?$ & 0.038 & 0.034 & 0 & \\
\hline VILLAGE312 & Does this household live in village $312 ?$ & 0.095 & 0.086 & 0 & \\
\hline VILLAGE313 & Does this household live in village $313 ?$ & 0.072 & 0.050 & 0 & \\
\hline VILLAGE321 & Does this household live in village $321 ?$ & 0.082 & 0.063 & 0 & 1 \\
\hline VILLAGE332 & Does this household live in village $332 ?$ & 0.054 & 0.045 & 0 & \\
\hline
\end{tabular}


Table 2: Sources of Income

\begin{tabular}{llccc}
\hline \multirow{2}{*}{$\%$ of Net Household Income in 1995 (INCOME) } & $\begin{array}{c}\text { Non-Market } \\
\text { Income }\end{array}$ & $\begin{array}{c}\text { Market } \\
\text { Income }\end{array}$ & Total \\
\hline On-Farm Income & Food Crop Income & 59 & 6 & 65 \\
& Cash Crop Income & n.a. & 17 & 17 \\
\cline { 2 - 5 } & Sub-Total & 59 & 23 & 82 \\
\hline Off-Farm Income & Entrepreneurial Income & n.a. & 10 & 10 \\
& Social and Wage Income & 2 & 6 & 8 \\
\cline { 2 - 5 } & Sub-Total & 2 & 16 & 18 \\
\hline Total & & 61 & 39 & 100 \\
\hline
\end{tabular}

Table 3: Household Income Shares in Sub-Saharan Africa

\begin{tabular}{lcccccc}
\hline \% of Total Income & \multicolumn{2}{c}{ On-Farm Income } & \multicolumn{2}{c}{ Off-Farm Income } & \multicolumn{2}{c}{ Social Income } \\
& FSP & SSA & FSP & SSA & FSP & SSA \\
\hline Maximum Survey & 100 & 86 & 0 & 8 & 0 & 4 \\
Mean of All Surveys & 82 & 63 & 16 & 28 & 2 & 8 \\
Median Survey & 88 & 63 & 12 & 20 & 0 & 16 \\
Minimum Survey & 18 & 37 & 82 & 51 & 45 & 11 \\
\hline
\end{tabular}

On-farm income includes food and cash crop income from home consumption and from crop sales. Off-farm income includes entrepreneurial and wage income. Social income includes remittances, transfers and donations. The three categories of income sum to give total income. The data reported under the headings "SSA" and "Mean of All Surveys" derived from 28 samples of farming households from Sub-Saharan Africa (abbreviated SSA) as calculated by (Delgado and Siamwalla 1999: p. 134). Most surveys covered a single agricultural year within the period 1985-89. The other data under the headings "SSA" refer to the mean values of one survey as defined below. "Maximum Survey", "Median Survey" and "Minimum Survey" refer to the income shares for the uplands area in Gambia in 1985-86, the Natural Region IV in Zimbabwe in 1988-89 and the Sahelian Zone in Senegal in 1988-90, respectively. The data under the "FSP" headings report the largest, mean, median and smallest value in the sample.

Table 4: Change in Crop Market Participation Status by Household

\begin{tabular}{lccccc}
\hline Estimated \% of Population & \multicolumn{4}{c}{ Crop Market Participation in 1994-95 (STATUS2) } \\
\cline { 2 - 6 } $\begin{array}{l}\text { Crop Market Participation in } \\
\text { 1993-94 (STATUS1) }\end{array}$ & $\begin{array}{c}\text { No Crop Market } \\
\text { Participation }\end{array}$ & $\begin{array}{c}\text { Sell Food } \\
\text { Crops } \\
\text { Only }\end{array}$ & $\begin{array}{c}\text { Sell Food } \\
\text { and Cash } \\
\text { Crops }\end{array}$ & $\begin{array}{c}\text { Sell Cash } \\
\text { Crops } \\
\text { Only }\end{array}$ & Total \\
\hline No Crop Market Participation & $\mathbf{6 . 0}$ & 3.7 & 1.7 & 1.7 & 13.1 \\
Sell Food Crops Only & 8.7 & $\mathbf{8 . 6}$ & 4.7 & 2.4 & 24.3 \\
Sell Food and Cash Crops & 0.8 & 4.6 & $\mathbf{1 5 . 5}$ & 5.4 & 26.2 \\
Sell Cash Crops Only & 6.0 & 7.8 & 10.1 & $\mathbf{1 2 . 5}$ & 36.4 \\
\hline Total & 21.4 & 24.7 & 31.9 & 21.9 & 100.0 \\
\hline
\end{tabular}



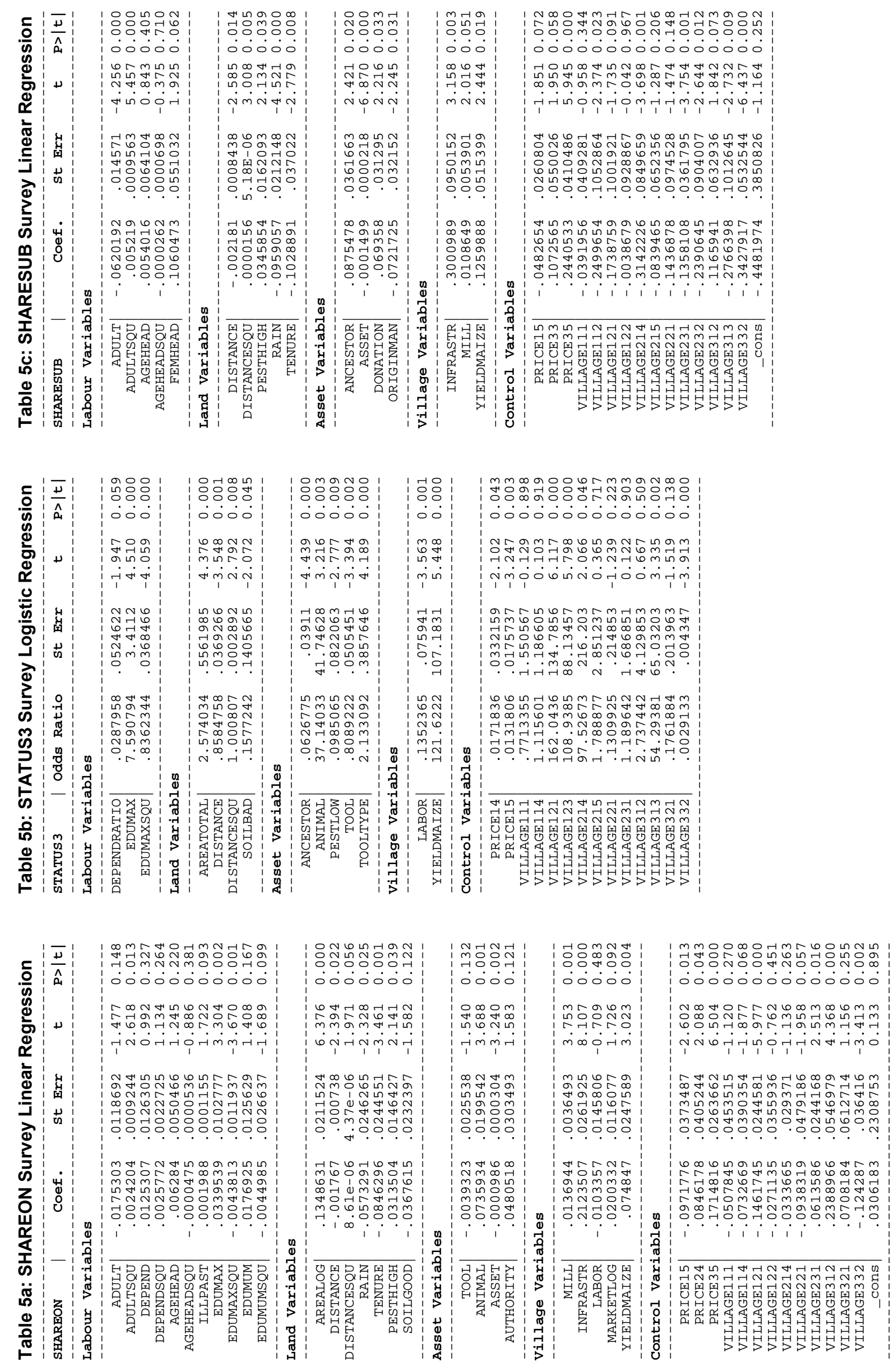

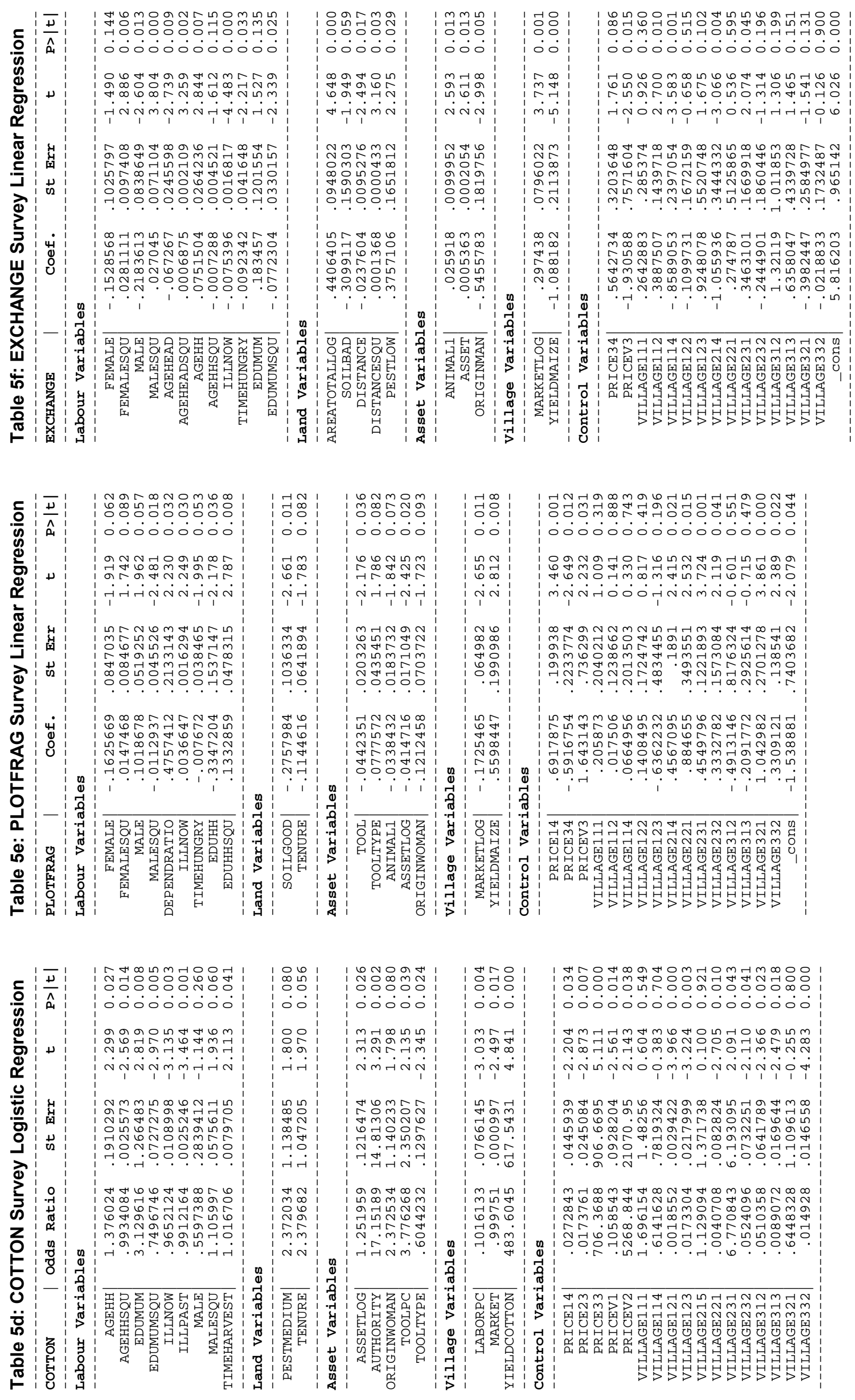


\section{References}

Abdulai, A. and C. L. Delgado (1999). "Determinants of Nonfarm Earnings of Farm-Based Husbands and Wives in Northern Ghana." American Journal of Agricultural Economics. 81(1): 117-30.

Adams, R. H. (2002). "Nonfarm Income, Inequality, and Land in Rural Egypt." Economic Development and Culture Change. 50(2): 339-63.

Addison, T. and C. de Sousa (1999). "Economic Reform and Economic Reconstruction in Mozambique." Evaluating Economic Liberalization. McGillivray, M. and O. Morrissey, Eds. Basingstoke: Macmillan Press: 163-85.

Appleton, S. and A. Balihuta (1996). "Education and Agricultural Productivity: Evidence from Uganda." Journal of International Development. 8(3): 415-44.

Bardhan, P. and C. Udry (1999). Development Microeconomics. Oxford: Oxford University Press.

Berry, S. (1993). No Condition Is Permanent: The Social Dynamics of Agrarian Change in Sub-Saharan Africa. Madison: University of Wisconsin Press.

Binswanger, H. P. and J. McIntire (1987). "Behavioral and Material Determinants of Production Relations in Land Abundant Tropical Agriculture." Economic Development and Cultural Change. 36(1): 73-99.

Blarel, B., P. Hazell, F. Place and J. Quiggin (1992). "The Economics of Farm Fragmentation: Evidence from Ghana and Rwanda." World Bank Economic Review. 6(2): 233-54.

Bodie, Z. and R. C. Merton (1998). Finance: Preliminary Edition. Upper Saddle River, NJ: Prentice Hall.

Brück, T. (2003). Land Access, Tenure and Investment in Post-War Northern Mozambique. DIW Berlin Discussion Paper. 358.

Carter, M. R. and P. Olinto (2003). "Getting Institutions "Right" for Whom: Credit Constraints and the Impact of Property Rights on the Quantity and Composition of Investment." American Journal of Agricultural Economics. 85(1): 173-86.

Chayanov, A. V. (1925). The Theory of the Peasant Economy: Irwin.

Corbett, J. (1988). "Famine and Household Coping Strategies." World Development. 16(9): 1099-112.

Cramer, C. and N. Pontara (1998). "Rural Poverty and Poverty Alleviation in Mozambique: What's Missing from the Debate?" Journal of Modern African Studies. 36(1): 101-38.

Cramer, J. S. and G. Ridder (1991). "Pooling States in Multinomial Logit Models." Journal of Econometrics. 47(2-3): 267-72.

Dasgupta, P. (1993). An Inquiry into Well-Being and Destitution. Oxford: Clarendon Press.

de Janvry, A., M. Fafchamps and E. Sadoulet (1991). "Peasant Household Behaviour with Missing Markets: Some Paradoxes Explained.” Economic Journal. 101(409): 1400-17.

de Sousa, C. (2003). "Rebuilding Rural Livelihoods and Social Capital in Mozambique." From Conflict to Recovery in Africa. Addison, T., Ed. Oxford: Oxford University Press: $51-72$. 
Delgado, C. L. and A. Siamwalla (1999). "Rural Economy and Farm Income Diversification in Developing Countries." Food Security, Diversification and Resource Management: Refocusing the Role of Agriculture? Proceedings of the Twenty-Third International Conference of Agricultural Economists Held at Sacramento, California, 10-16 August 1997. Peters, G. H. and J. von-Braun, Eds. Aldershot, U.K., and Brookfield, Vt.: Ashgate: 126-43.

Dercon, S. (2002). "Income Risk, Coping Strategies, and Safety Nets." World Bank Research Observer. 17(2): 141-66.

Dercon, S. and P. Krishnan (1996). "Income Portfolios in Rural Ethiopia and Tanzania: Choices and Constraints." Journal of Development Studies. 32(6): 850-75.

Dercon, S. and P. Krishnan (2000). "In Sickness and in Health: Risk Sharing within Households in Rural Ethiopia.” Journal of Political Economy. 108(4): 688-727.

Dixit, A. K. (1990). Optimization in Economic Theory. Oxford: Oxford University Press.

Ellis, F. (1998). "Household Strategies and Rural Livelihood Diversification." Journal of Development Studies. 35(1): 1-38.

Ellis, F. (2000). Rural Livelihoods and Diversity in Developing Countries. Oxford: Oxford University Press.

Fafchamps, M. and S. Lund (2003). "Risk-Sharing Networks in Rural Philippines." Journal of Development Economics. 71(2): 261-87.

Garrett, J. L. and M. T. Ruel (1999). “Are Determinants of Rural and Urban Food Security and Nutritional Status Different? Some Insights from Mozambique." World Development. 27(11): 1955-75.

Goetz, S. J. (1992). “A Selectivity Model of Household Food Marketing Behaviour in SubSaharan Africa." American Journal of Agricultural Economics. 74: 444-52.

Heltberg, R. and F. Tarp (2002). "Agricultural Supply Response and Poverty in Mozambique." Food Policy. 27(2): 103-24.

Key, N., E. Sadoulet and A. de Janvry (2000). "Transaction Costs and Agricultural Household Supply Response.” American Journal of Agricultural Economics. 82: 245-59.

Leonard, M. (2000). "Coping Strategies in Developed and Developing Societies: The Working of the Informal Economy." Journal of International Development. 12(8): 1096-85.

Liedholm, C., M. McPherson and E. Chuta (1994). "Small Enterprise Employment Growth in Rural Africa.” American Journal of Agricultural Economics. 76: 1177-82.

MAP/MSU Research Team (1996). 1994/96 Nampula/Cabo Delgado Socio-Economic Study: Organization of Primary Data and Questionnaires. Maputo: Ministry of Agriculture and Fisheries.

Ministério da Agricultura (1994). Unpublished Data. Maputo.

Pitcher, M. A. (1998). "Disruption without Transformation: Agrarian Relations and Livelihoods in Nampula Province, Mozambique, 1975-1995." Journal of Southern African Studies. 24(1): 115-40. 
Platteau, J.-P. (1999). "Traditional Systems of Social Security and Hunger Insurance: Past Achievements and Modern Challenges." Social Security in Developing Countries. Ahmad, E., J. Drèze, J. Hills and A. Sen, Eds. New Delhi: Oxford University Press: 112-70.

Reardon, T. (1997). "Using Evidence of Household Income Diversification to Inform Study of the Rural Nonfarm Labour Market in Africa." World Development. 25(5): 735-47.

Reardon, T., C. Delgado and P. Matlon (1992). "Determinants and Effects of Income Diversification Amongst Farm Households in Burkina-Faso." Journal of Development Studies. 28(2): 264-96.

Reardon, T., P. Matlon and C. Delgado (1988). "Coping with Household-Level Food Insecurity in the Drought-Affected Areas of Burkina Faso." World Development. 16: 1065-74.

Sperling, L. and C. Longley (2002). "Beyond Seeds and Tools; Effective Support to Farmers in Emergencies." The Journal of Disaster Studies, Policy and Management. 26(4).

Taylor, J. E. and A. Yunez-Naude (2000). "The Returns from Schooling in a Diversified Rural Economy." American Journal of Agricultural Economics. 82: 287-97.

Townsend, R. F. (1999). "Agricultural Incentives in Sub-Saharan Africa: Policy Challenges." Technical Paper. Washington, D.C.: World Bank. 444.

Tschirley, D. and R. Benfica (2001). "Smallholder Agriculture, Wage Labour and Rural Poverty Alleviation in Land-Abundant Areas of Africa: Evidence from Mozambique." Journal of Modern African Studies. 39(2): 333-58.

Tschirley, D. L. and M. T. Weber (1994). "Food Security Strategies under Extremely Adverse Conditions: The Determinants of Household Income and Consumption in Rural Mozambique." World Development. 22(2): 159-73.

UNDP (1999). Mozambique National Human Development Report 1999. Maputo.

von Braun, J. and E. Kennedy (1994). Agricultural Commercialization, Economic Development, and Nutrition. Baltimore: Johns Hopkins University Press.

von Braun, J. and R. Pandya-Lorch (1991). "Income Sources of Malnourished People in Rural Areas: Microlevel Information and Policy Implications." Working Papers on Commercialization of Agriculture and Nutrition. Washington, D.C.: International Food Policy Research Institute. 5.

Webb, P. and J. von Braun (1994). Famine and Food Security in Ethiopia: Lessons for Africa. Chichester: Wiley.

World Bank (2002). World Development Indicators. Washington D.C.

Wuyts, M. (2003). "The Agrarian Question in Mozambique's Transition and Reconstruction." From Conflict to Recovery in Africa. Addison, T., Ed. Oxford: Oxford University Press: $141-54$. 